\title{
Simple Sequence Repeat (SSR) Marker Assay-Based Genetic Diversity among Dolichos Bean (Lablab purpureus L. Sweet) Advanced Breeding Lines Differing for Productivity per se Traits
}

\author{
C.M. Keerthi" , S. Ramesh, M. Byregowda and P.V. Vaijayanthi \\ Department of Genetics and Plant Breeding, University of Agricultural Sciences, \\ Bengaluru-65, Karnataka, India \\ *Corresponding author
}

\begin{tabular}{|c|c|}
\hline & T D \\
\hline & \multirow{6}{*}{$\begin{array}{l}\text { Increased and continued use of the diverse genotypes is a prerequisite for developing and } \\
\text { diversifying the genetic base of crop cultivars. DNA markers which are crop-stage non- } \\
\text { specific environmental neutral, easily assayable and amenable for automation are being } \\
\text { used to assess the diversity of germplasm accessions and/or breeding lines. DNA markers } \\
\text { also provide information on the population structure, allelic richness, and parameters that } \\
\text { specify diversity among the genotypes to help breeders to choose those most appropriate } \\
\text { for use in cultivar development. Hence SSR markers were used to assess diversity at } \\
\text { marker loci among } 16 \text { phenotypically diverse dolichos bean genotypes. In the present } \\
\text { study, } 52 \text { of } 55 \text { SSR-based markers were polymorphic, resulting in } 94.55 \% \text { polymorphism. } \\
\text { Amplification of genomic DNA segments complementary to 55 SSR primers resulted in } \\
133 \text { scorable alleles with an average of } 2.5 \text { alleles per SSR loci. SSR markers exhibited } \\
\text { differential ability to discriminate } 16 \text { genotypes as indicated by the estimates of effective } \\
\text { multiplex ratio which ranged from } 1.89 \text { to } 4.73 \text { and marker index ranged from } 0.69 \text { to } 3.40 \text {. } \\
\text { The average gene diversity in the present study is more than that reported in dolichos bean. } \\
\text { The estimates of Shanon's diversity index complemented those of average gene diversity. } \\
\text { These results indicate that these SSR markers are highly informative and could be used to } \\
\text { assess genetic diversity among the genotypes. The genotypes, HA } 10-8 \text {, FPB } 15 \text { and RIL } \\
162 \text { share different alleles, FPB } 8 \text { and RIL } 21 \text { share similar alleles. Hence, the genotypes, } \\
\text { HA 10-8, FPB } 15 \text { and RIL } 162 \text { could be used in crossing programme to derive genotypes } \\
\text { with combination of desired traits. }\end{array}$} \\
\hline Keywo & \\
\hline & \\
\hline Artic & \\
\hline & \\
\hline & \\
\hline
\end{tabular}

\section{Introduction}

Dolichos bean is one of the ancient crops widely distributed in Indian subcontinent, Africa, and Southeast Asia (Smartt, 1985), where it has been used as a grain legume and vegetable for more than 3500 years (Fuller, 2003). Despite its wide distribution in the tropics and range of adaptability and diversity, it remains as an important, but underutilized crop in many of these regions (Engle and Altoveros, 2000), as evidenced from limited area planted to this crop and efforts towards its genetic improvement (Ramesh and Byregowda, 2016). However, it's utility as a vegetable and pulse (Ramesh and Byregowda, 
2016), and/or forage crop (Magoon et al., 1974) in tropical regions with humid to semiarid climates has resulted in re-assessing its potential in tropical farming systems (Pengelly and Lisson, 2003). A wide use of underutilized crop species such as dolichos bean would contribute to temporal and spatial heterogeneity into agricultural production systems and hence sustainable supply of diverse nutritious food (Ebert, 2014). It can contribute to food security and better nutrition, increased income to rural poor, ecosystem stability and cultural diversity associated with local food habits (Ebert, 2014). Enhancement of its economic value through the development of widely adapted high yielding cultivars with broad genetic base is expected to offer competitive edge to dolichos bean to enable its popularity and wider cultivation (Ramesh and Byre Gowda, 2016).

Increased and continued use of the diverse genotypes is a prerequisite for developing and diversifying the genetic base of crop cultivars. DNA markers which are crop-stage nonspecific environmental neutral, easily assayable and amenable for automation are being used to assess the diversity of germplasm accessions and/or breeding lines. DNA markers also provide information on the population structure, allelic richness, and parameters that specify diversity among the genotypes to help breeders to choose those most appropriate for use in cultivar development. Of late, DNA marker-based genetic diversity assessment has gained importance due to the speed and quality of data generated.

Of the several DNA-based markers those based on simple sequence repeats (SSR) are now the markers of choice in various applications of plant breeding research as they are co-dominant, multi-allelic, highly polymorphic even between closely related lines, require low quantity of DNA, easily automated for high throughput genotyping, and are highly transferable between populations (Benabdelmouna et al., 2001). The objective of the present investigation is to assess phenotypically diverse dolichos bean genotypes at SSR marker loci.

\section{Materials and Methods}

\section{Plant material and experimental design}

The material for the study consisted of 16 phenotypically diverse genotypes which include two released varieties (HA 3 and HA 4), six advanced breeding lines (ABL) (HA 11-3, HA 10-8, FPB 3, FPB 8, FPB 15 and FPB 21) and eight recombinant inbred lines (RIL 11, RIL 162, RIL 185, RIL 332, RIL 180, RIL 60, RIL 21 and RIL 25) (Keerthi et al., 2015). Among these, HA 3, HA 4, HA 113, HA 10-8, FPB 3, FPB 8, FPB 15, FPB 21, RIL 162, RIL 185, RIL 180 and RIL 60 are high yielding with greater number of branches, racemes plant ${ }^{-1}$ and pods plant ${ }^{-1}$. The remaining genotypes (RIL 11, RIL 332, RIL 21 and RIL 25) are low yielding with fewer number of branches plant ${ }^{-1}$, racemes plant ${ }^{-1}$ and pods plant ${ }^{-1}$. The genotypes are being maintained at All India Coordinated Research Project (AICRP) on pigeonpea, University of Agricultural Sciences (UAS), Bengaluru, India.

\section{SSR marker assay}

The total genomic DNA from 16 genotypes was extracted from young leaves using the Cetyl Trimethyl Ammonium Bromide method (Doyle and Doyle, 1987). The quality and quantity of extracted genomic DNA of all the 16 genotypes were checked using $0.8 \%$ agarose gel. A total of 55 dolichos bean specific expressed sequence tag (EST)-based SSR markers (Table 1) were used for genotyping 16 genotypes at the Plant Molecular Biological Laboratory, Department 
of Genetics and Plant Breeding (GPB), UAS, Bengaluru.

The SSR priming regions of 16 genotypes were amplified using PCR with Taq DNA polymerase. PCR mixtures contained approximately $2.0 \mu \mathrm{l}$ of DNA (30ng per $\mu \mathrm{l}$ ), $0.3 \mu \mathrm{l} \mathrm{Taq}$ polymerase $(1$ unit per $\mu \mathrm{l}), 1.0 \mu \mathrm{l}$ 10X TE buffer, $0.5 \mu 1$ DNTPs $(2 \mathrm{mM})$ and 1.0 $\mu \mathrm{l}$ each of forward and reverse primers $(1 \mu \mathrm{M})$ in a total of $10 \mu \mathrm{l}$ solution. The PCR cycle consisted of $5 \mathrm{~min}$ at $95^{\circ} \mathrm{C}$ (hot start), 0.30 min at $95^{\circ} \mathrm{C}$ (denaturation), $1 \mathrm{~min}$ at 50,54 and $56^{\circ} \mathrm{C}$ (annealing), $1 \mathrm{~min}$ at $72^{\circ} \mathrm{C}$ (extension), $10 \mathrm{~min}$ at $72^{\circ} \mathrm{C}$ (final extension) followed by infinite time at $4^{0} \mathrm{C}$ for holding. The denaturation, annealing and extension step were carried out for 40 cycles. The PCR products were loaded on 4 per cent hi-media agrose gel in $1 \mathrm{X}$ TAE buffer stained with ethidium bromide and bromophenol blue as loading dye. Amplicons were separated in an electrophoresis unit at $80 \mathrm{~V}$ for five hours using 1X TAE buffer.

\section{Scoring of SSR marker data}

The different sized amplicons of SSR priming regions of genomic DNA at defined product size range (the amplicons in the same row) were scored as different alleles at each of the SSR marker locus. The variation in amplicon intensity was not taken into consideration to avoid confusion in scoring.

\section{Estimation of population genetic parameters}

Various population genetic parameters such as polymorphic SSR loci, polymorphic information content (PIC), Nei's average gene diversity, average number of alleles per locus, effective number of alleles per locus and major and minor allele frequency were estimated using the software, Power Marker V3.25 (Liu and Muse, 2005).

\section{Results and Discussion}

\section{SSR marker assay-based polymorphism}

In general, expressed sequences are conserved across genotypes within a species. Hence, EST-based SSR markers generally show lower polymorphism compared to those based on genomic SSR markers (Saha et al., 2006). However, in the present study, 52 of 55 EST SSR-based markers were polymorphic, resulting in $94.55 \%$ polymorphism which was higher than that based on genomic SSRs (25$50 \%$ ) in dolichos bean (Zhong et al., 2008; Zhang et al., 2013). A study by Woodhead et $a l .$, (2005) indicated that the differentiation of gentypes based on EST-SSRs was comparable to that based on genomic SSRs and AFLPs. Polymorphic information content (PIC) is yet another measure of genetic diversity at a marker locus. The estimates of PIC ranged from 0.34 to 0.68 (Table 1). Higher the PIC values, higher is the amount of information which can be derived from a marker locus. Based on the criteria reported by Botstein et al., (1980), 21 of the 52 polymorphic SSR loci were highly informative (PIC > 0.5) and the remaining 31 SSR markers were reasonably informative $(0.5>$ PIC > 0.25). Thus, present results indicate large differences at SSR marker loci used in the study.

\section{Allelic richness and discriminating ability of SSR markers}

Amplification of genomic DNA segments complementary to 55 SSR primers resulted in 133 scorable alleles with an average of 2.5 alleles per SSR loci. The number of alleles per loci varied from 1 to 5 (Table 2). As many as 18 markers were tri-allelic, four were tetraallelic and one was penta-allelic (most informative); 29 were biallelic and 3 were mono-allelic (least informative). Major allele frequency ranged from 0.75 (KTD 250) to 0.31 (KTD 241) with an average of 0.56. 
Int.J.Curr.Microbiol.App.Sci (2018) 7(5): 3736-3744

Table.1 List of SSR primers used to characterize genotypes in dolichos bean

\begin{tabular}{|c|c|c|c|c|}
\hline $\begin{array}{l}\text { SI. } \\
\text { No }\end{array}$ & $\begin{array}{c}\text { Primer } \\
\text { name }\end{array}$ & Forward primer (5'-3') & Reverse primer $\left(5^{\prime}-3^{\prime}\right)$ & $\begin{array}{c}\text { Annealing } \\
\text { Temp }\end{array}$ \\
\hline 1 & KTD120 & TGTAGAGTGGGAGTTAGTGTTGT & GAAGTACAAAGACCCTACTCCAG & 56 \\
\hline 2 & KTD129 & CTGCATGCGTATAATAGAGAAG & CCTCACACTGTATTACTGAGCTT & 56 \\
\hline 3 & KTD130 & CAGAGTATAAAGGAGAGGAGTCAT & CTCACAATTGTTTAGGTGGAAG & 56 \\
\hline 4 & KTD132 & GTAACAGTTATAGCTTGCTGTCG & СТТСТССТААТТСТССТТСАСТТС & 56 \\
\hline 5 & KTD133 & GATGAAGGTGAAGAGAGTATGAGT & TAGCAGTGAAGAAGTGAGTGAGTA & 56 \\
\hline 6 & KTD138 & GATGAAGAAGGTTGTAGAGTTGTG & СТАТСТСАСАСТТТССТТАСАССТ & 56 \\
\hline 7 & KTD140 & GTGCCTCATAATTCTCTCTGTC & GCATGAAGTGTTAGCTACAGAA & 56 \\
\hline 8 & KTD144 & СТTТСТССТТСТСТTТСТСАСТС & GAAGACGGGTAGTTCCTAGTTAT & 56 \\
\hline 9 & KTD147 & TCTGTGAACTAAGCTGAAACAG & GAGGCTCAAAGTAGTAGATGATG & 56 \\
\hline 10 & KTD150 & AGACTACAATGTCTTGACACACC & TGTAGTAGTGTGGTGTTAGTTCTG & 56 \\
\hline 11 & KTD159 & GGGTTACTAGTAGTGGAAGAAGAA & GGGAGTCAACAATAACCCTAATAC & 56 \\
\hline 12 & KTD162 & ACACTGTTTGACTTAGAACTAGCC & GATTGTGGTACTCTCTTCTCAAG & 56 \\
\hline 13 & KTD171 & TAGCAGACAGAGTCTGAGATTAAG & CTCGTGTGTAGATTCAGAGTTAAG & 56 \\
\hline 14 & KTD182 & AGTGGGATCAACTAATTCTGAC & ACTGGACCAAGTTATCAAACAC & 56 \\
\hline 15 & KTD183 & TACCAGAGACTAATTGAACGTG & CTACCTCAGTCTTCGTTCTCTATC & 56 \\
\hline 16 & KTD184 & TCATTTCCAAGCTTCTGTAGTC & GAGTCGAAGAGTATGGAGAGAA & 56 \\
\hline 17 & KTD185 & ATTCGTGATCAGTGAGTTGTCT & TACTGCTACTCCATACCCTAGAAT & 56 \\
\hline 18 & KTD193 & AGAGAGATCCTTGAGAGAAACAC & TGGTCCATACTCAGACTACTAAGA & 56 \\
\hline 19 & KTD195 & TGGTTGAATGAGAGAGTAAAGG & GTTTCTTCAAGGTACATGTCTCAC & 56 \\
\hline 20 & KTD199 & ТTСТTСТСТТСААСТТСАСТСС & ACGAAGACAAGGAAGAGAAATC & 56 \\
\hline 21 & KTD200 & CTGAACTCACTTCTACСТTCTTCT & AAGACATGAGCATGTAGTGGTA & 56 \\
\hline 22 & KTD201 & GAAGCTAAATTCCTCСТCTTCT & GTTTAAGGATTCTTCTGACGAC & 56 \\
\hline 23 & KTD207 & GAGGTATCAGACTCATCACATTC & CCTATATTCGACATTCGTTCTC & 56 \\
\hline 24 & KTD209 & GTTGTGTCATGCCATAGCTGTAT & CTGATTATCACTCTGAGAAGAGG & 56 \\
\hline 25 & KTD225 & GTCTTTCACCATTTCTTCCTC & GTGTACACAGACACACACGATAC & 56 \\
\hline 26 & KTD233 & AGGTTGTAAGAGTGAGAAGGAA & GGATAGATAGACCTCAGAAGAAGA & 56 \\
\hline 27 & KTD240 & GCTCAATGTGAATGAAACAGAC & GACTCАСТССАТТСТСТСТААСТT & 56 \\
\hline 28 & KTD241 & GTTAAGCCTTGAGATCTGACAC & СТTCАССТСАСТСАСААСАТТ & 56 \\
\hline 29 & KTD245 & AAGGAGAGAGTTAAGGTTGTAGAG & AAAAGTGCCACATTCTCTCTC & 56 \\
\hline 30 & KTD249 & ACTACCCTATAGTCTCTCTGTGCT & AGAAGATGATCTCAGATTCCAC & 56 \\
\hline 31 & KTD250 & GAGGAATCTGAGTTGGAGACTAC & ACTGTCССТCTCATTCACTTT & 56 \\
\hline 32 & KTD251 & GTCTTGAAGAGTTTAGAGACGAGT & CTTAACATCACAACACAACACC & 56 \\
\hline 33 & KTD252 & CAGGTAAGTAGGAAGAAACAAGAG & CTTCTCGTGTTCACAAACAAC & 56 \\
\hline 34 & KTD254 & TGAGAAGTTAACAGACAGAGAGAG & TCACАСТСТСАТСААСССТАС & 56 \\
\hline 35 & KTD262 & CGGCTCTATGAATGTAATACTGAG & AAACGGCGAAGAGTTAAGAT & 56 \\
\hline 36 & KTD266 & CTTGGTCACCTTTCTCATGT & GTTTCTTGTTTCCTCCAACTAC & 56 \\
\hline 37 & KTD267 & GAAACCTCAAATACGAACTCC & CCAGGTAGTGGTAGTAGTAGTAGGA & 56 \\
\hline 38 & KTD279 & AGTCTAGTCTACCACCTAAAGCAC & GATAGAGGAGTTGCTGCATTAT & 56 \\
\hline 39 & KTD280 & TGGGAGATTTGTCTTGTAGTAGAG & AGTAGAATAGGCAAAGGCAAC & 56 \\
\hline 40 & KTD289 & ACACCACATCACACACTTATTC & CTTGCTGACTGTTCTCCATT & 56 \\
\hline 41 & KTD296 & CTATCGACCTCCTCTCTACTCTC & AATACTACCAGCCGATTTCCT & 56 \\
\hline 42 & KTD121 & CAGTTTAGGAAGAGTACATTGGAG & CTATTGAACACTCCGCCTTATAG & 54 \\
\hline 43 & KTD142 & GAGACCTTCTCTTGCTAGTTTCT & ATАСТТСАСТССТССТАСТТСААС & 54 \\
\hline 44 & KTD203 & GTGTACCATAGGAGAATGACAA & ATGTTGTAGAGACAGAGAGAGACA & 54 \\
\hline 45 & KTD206 & GGAAAGCACTCATTATTCAGAC & ATAAACGTAGTTGCCACTCTCT & 54 \\
\hline 46 & KTD211 & TACAGAAGAGAACCGTGTAAGA & CATACAATACAACGTCCACAAC & 54 \\
\hline 47 & KTD255 & GAACTGAAAGAGAGGGATGAT & GGGCAGAGAGACAGTAATAATAAG & 54 \\
\hline 48 & KTD261 & CTTGAGAAACTCCACCATGT & CGAGGAGAGAAACAGAGATAGAT & 54 \\
\hline 49 & KTD272 & AATCTTAACAGGGTCAGAAGC & СТСТСССТСССАТААСТААСТТ & 54 \\
\hline 50 & KTD275 & CTCTTGTTCGTACTCTTCCTATTC & CAGATGAGAAGGACCGTTAAT & 54 \\
\hline 51 & KTD116 & GATACTGAAAACAGCTCCTTACC & CTCCTCTGAGTCTCTTCATGTTA & 50 \\
\hline 52 & KTD243 & ATCGATAGTGCAGAGAAGCTAT & GATCTCCGTCAGGTTAGAAAC & 50 \\
\hline 53 & KTD269 & CATCAGAGAGAAACTTGTGTTG & СТCTCACTCTCTTCCTCGTTC & 50 \\
\hline 54 & KTD293 & CTTGCCCTTGTAATAGAGGTC & ATCTTCTCCGACTCATTTCC & 50 \\
\hline 55 & KTD131 & TTCССТССТTCATATAGTTGAC & TTACAGACCTAAGTTCAAGAGG & 50 \\
\hline
\end{tabular}


Table. 2 Estimates of population genetic parameters based on SSR marker profile of 16 dolichos bean genotypes

\begin{tabular}{|c|c|c|c|c|c|c|c|c|c|c|c|}
\hline $\begin{array}{l}\text { SI. } \\
\text { No. }\end{array}$ & Markers & $\begin{array}{l}\text { Number } \\
\text { of alleles }\end{array}$ & $\begin{array}{l}\text { Major allele } \\
\text { frequency }\end{array}$ & $\begin{array}{l}\text { Minor allele } \\
\text { frequency }\end{array}$ & $\begin{array}{l}\text { Effective } \\
\text { number of } \\
\text { alleles }\end{array}$ & $\begin{array}{l}\text { Nei's gene } \\
\text { diversity }\end{array}$ & $\begin{array}{l}\text { Corrected } \\
\text { gene } \\
\text { diversity }\end{array}$ & PIC & $\begin{array}{l}\text { Shannon's } \\
\text { Information } \\
\text { index }\end{array}$ & EMR & MI \\
\hline 1 & KTD184 & 4 & 0.50 & 0.06 & 2.72 & 0.63 & 0.65 & 0.57 & 1.14 & 3.78 & 2.39 \\
\hline 2 & KTD241 & 4 & 0.31 & 0.13 & 3.66 & 0.73 & 0.75 & 0.68 & 1.33 & 3.78 & 2.75 \\
\hline 3 & KTD245 & 4 & 0.56 & 0.07 & 2.37 & 0.58 & 0.60 & 0.59 & 1.08 & 3.78 & 2.19 \\
\hline 4 & KTD249 & 5 & 0.44 & 0.06 & 3.56 & 0.72 & 0.74 & 0.68 & 1.42 & 4.73 & 3.40 \\
\hline 5 & KTD250 & 2 & 0.75 & 0.20 & 1.47 & 0.32 & 0.33 & 0.35 & 0.50 & 1.89 & 0.61 \\
\hline 6 & KTD251 & 2 & 0.69 & 0.27 & 1.64 & 0.39 & 0.40 & 0.40 & 0.58 & 1.89 & 0.74 \\
\hline 7 & KTD262 & 2 & 0.63 & 0.33 & 1.80 & 0.44 & 0.46 & 0.43 & 0.64 & 1.89 & 0.84 \\
\hline 8 & KTD266 & 3 & 0.44 & 0.19 & 2.72 & 0.63 & 0.65 & 0.56 & 1.04 & 2.84 & 1.79 \\
\hline 9 & KTD267 & 2 & 0.69 & 0.27 & 1.64 & 0.39 & 0.40 & 0.40 & 0.58 & 1.89 & 0.74 \\
\hline 10 & KTD280 & 3 & 0.56 & 0.06 & 2.17 & 0.54 & 0.56 & 0.45 & 0.86 & 2.84 & 1.53 \\
\hline 11 & KTD195 & 3 & 0.38 & 0.20 & 2.78 & 0.64 & 0.66 & 0.62 & 1.05 & 2.84 & 1.82 \\
\hline 12 & KTD193 & 2 & 0.69 & 0.31 & 1.75 & 0.43 & 0.44 & 0.34 & 0.62 & 1.89 & 0.81 \\
\hline 13 & KTD203 & 2 & 0.56 & 0.44 & 1.97 & 0.49 & 0.51 & 0.37 & 0.69 & 1.89 & 0.93 \\
\hline 14 & KTD206 & 3 & 0.63 & 0.13 & 2.13 & 0.53 & 0.55 & 0.47 & 0.90 & 2.84 & 1.51 \\
\hline 15 & KTD211 & 2 & 0.56 & 0.44 & 1.97 & 0.49 & 0.51 & 0.37 & 0.69 & 1.89 & 0.93 \\
\hline 16 & KTD255 & 3 & 0.38 & 0.27 & 2.92 & 0.66 & 0.68 & 0.64 & 1.09 & 2.84 & 1.87 \\
\hline 17 & KTD272 & 3 & 0.44 & 0.07 & 2.27 & 0.56 & 0.58 & 0.53 & 0.89 & 2.84 & 1.59 \\
\hline 18 & KTD275 & 2 & 0.63 & 0.38 & 1.88 & 0.47 & 0.48 & 0.36 & 0.66 & 1.89 & 0.89 \\
\hline 19 & KTD296 & 2 & 0.63 & 0.38 & 1.88 & 0.47 & 0.48 & 0.36 & 0.66 & 1.89 & 0.89 \\
\hline 20 & KTD116 & 2 & 0.69 & 0.31 & 1.75 & 0.43 & 0.44 & 0.34 & 0.62 & 1.89 & 0.81 \\
\hline 21 & KTD243 & 2 & 0.63 & 0.38 & 1.88 & 0.47 & 0.48 & 0.36 & 0.66 & 1.89 & 0.89 \\
\hline 22 & KTD185 & 3 & 0.50 & 0.19 & 2.61 & 0.62 & 0.64 & 0.54 & 1.02 & 2.84 & 1.75 \\
\hline 23 & KTD200 & 2 & 0.56 & 0.44 & 1.97 & 0.49 & 0.51 & 0.37 & 0.69 & 1.89 & 0.93 \\
\hline 24 & KTD201 & 3 & 0.56 & 0.13 & 2.23 & 0.55 & 0.57 & 0.55 & 0.93 & 2.84 & 1.56 \\
\hline 25 & KTD207 & 2 & 0.56 & 0.44 & 1.97 & 0.49 & 0.51 & 0.37 & 0.69 & 1.89 & 0.93 \\
\hline 26 & KTD209 & 2 & 0.69 & 0.27 & 1.64 & 0.39 & 0.40 & 0.40 & 0.58 & 1.89 & 0.74 \\
\hline 27 & KTD225 & 4 & 0.50 & 0.07 & 2.65 & 0.62 & 0.64 & 0.62 & 1.14 & 3.78 & 2.35 \\
\hline 28 & KTD233 & 2 & 0.69 & 0.21 & 1.51 & 0.34 & 0.35 & 0.43 & 0.52 & 1.89 & 0.64 \\
\hline 29 & KTD289 & 3 & 0.50 & 0.25 & 2.67 & 0.63 & 0.65 & 0.55 & 1.04 & 2.84 & 1.77 \\
\hline 30 & KTD252 & 2 & 0.56 & 0.44 & 1.97 & 0.49 & 0.51 & 0.37 & 0.69 & 1.89 & 0.93 \\
\hline 31 & KTD147 & 3 & 0.50 & 0.13 & 2.46 & 0.59 & 0.61 & 0.51 & 0.97 & 2.84 & 1.68 \\
\hline 32 & KTD144 & 3 & 0.56 & 0.19 & 2.42 & 0.59 & 0.60 & 0.52 & 0.98 & 2.84 & 1.66 \\
\hline 33 & KTD133 & 2 & 0.69 & 0.31 & 1.75 & 0.43 & 0.44 & 0.34 & 0.62 & 1.89 & 0.81 \\
\hline 34 & KTD240 & 3 & 0.63 & 0.13 & 2.13 & 0.53 & 0.55 & 0.47 & 0.90 & 2.84 & 1.51 \\
\hline 35 & KTD199 & 3 & 0.44 & 0.19 & 2.72 & 0.63 & 0.65 & 0.56 & 1.04 & 2.84 & 1.79 \\
\hline 36 & KTD254 & 2 & 0.56 & 0.44 & 1.97 & 0.49 & 0.51 & 0.37 & 0.69 & 1.89 & 0.93 \\
\hline 37 & KTD120 & 2 & 0.56 & 0.44 & 1.97 & 0.49 & 0.51 & 0.37 & 0.69 & 1.89 & 0.93 \\
\hline 38 & KTD140 & 3 & 0.56 & 0.13 & 2.33 & 0.57 & 0.59 & 0.50 & 0.95 & 2.84 & 1.62 \\
\hline 39 & KTD142 & 3 & 0.50 & 0.13 & 2.46 & 0.59 & 0.61 & 0.51 & 0.97 & 2.84 & 1.68 \\
\hline 40 & KTD279 & 2 & 0.50 & 0.50 & 2.00 & 0.50 & 0.52 & 0.38 & 0.69 & 1.89 & 0.95 \\
\hline 41 & KTD150 & 2 & 0.56 & 0.40 & 1.92 & 0.48 & 0.50 & 0.45 & 0.67 & 1.89 & 0.91 \\
\hline 42 & KTD159 & 2 & 0.56 & 0.40 & 1.92 & 0.48 & 0.50 & 0.45 & 0.67 & 1.89 & 0.91 \\
\hline 43 & KTD162 & 2 & 0.63 & 0.38 & 1.88 & 0.47 & 0.48 & 0.36 & 0.66 & 1.89 & 0.89 \\
\hline 44 & KTD171 & 2 & 0.50 & 0.47 & 1.99 & 0.50 & 0.51 & 0.46 & 0.69 & 1.89 & 0.94 \\
\hline 45 & KTD182 & 2 & 0.56 & 0.44 & 1.97 & 0.49 & 0.51 & 0.37 & 0.69 & 1.89 & 0.93 \\
\hline 46 & KTD183 & 2 & 0.69 & 0.31 & 1.75 & 0.43 & 0.44 & 0.34 & 0.62 & 1.89 & 0.81 \\
\hline 47 & KTD129 & 3 & 0.63 & 0.13 & 1.99 & 0.50 & 0.51 & 0.51 & 0.86 & 2.84 & 1.41 \\
\hline 48 & KTD121 & 2 & 0.50 & 0.50 & 2.00 & 0.50 & 0.52 & 0.38 & 0.69 & 1.89 & 0.95 \\
\hline 49 & KTD130 & 2 & 0.56 & 0.44 & 1.97 & 0.49 & 0.51 & 0.37 & 0.69 & 1.89 & 0.93 \\
\hline 50 & KTD132 & 3 & 0.50 & 0.13 & 2.46 & 0.59 & 0.61 & 0.51 & 0.97 & 2.84 & 1.68 \\
\hline 51 & KTD131 & 2 & 0.44 & 0.50 & 2.00 & 0.50 & 0.52 & 0.53 & 0.69 & 1.89 & 0.95 \\
\hline \multirow[t]{2}{*}{52} & KTD138 & 3 & 0.44 & 0.21 & 2.65 & 0.62 & 0.64 & 0.66 & 1.03 & 2.84 & 1.77 \\
\hline & Mean & 2.65 & 0.56 & 0.27 & 2.17 & 0.49 & 0.51 & - & - & - & - \\
\hline
\end{tabular}

PIC: Polymorphic information content;

EMR: Effective multiplex ratio; MI: Marker index 
Table.3 Inter genotypic distance between 16 dolichos bean genotypes based on SSR marker profile

\begin{tabular}{|c|c|c|c|c|c|c|c|c|c|c|c|c|c|c|c|}
\hline Genotypes & HA 3 & HA 4 & HA 11-3 & RIL 11 & RIL 185 & FPB 8 & FPB 15 & RIL 332 & FPB 3 & RIL 162 & HA 10-8 & FPB 21 & RIL 21 & RIL 25 & RIL 60 \\
\hline HA 4 & 0.42 & & & & & & & & & & & & & & \\
\hline HA 11-3 & 0.49 & 0.56 & & & & & & & & & & & & & \\
\hline RIL 11 & 0.47 & 0.51 & 0.38 & & & & & & & & & & & & \\
\hline RIL 185 & 0.42 & 0.47 & 0.53 & 0.60 & & & & & & & & & & & \\
\hline FPB 8 & 0.62 & 0.49 & 0.51 & 0.53 & 0.58 & & & & & & & & & & \\
\hline FPB 15 & 0.45 & 0.55 & 0.56 & 0.56 & 0.58 & 0.60 & & & & & & & & & \\
\hline RIL 332 & 0.40 & 0.55 & 0.45 & 0.40 & 0.44 & 0.47 & 0.51 & & & & & & & & \\
\hline FPB 3 & 0.60 & 0.44 & 0.49 & 0.44 & 0.56 & 0.67 & 0.55 & 0.42 & & & & & & & \\
\hline RIL 162 & 0.40 & 0.44 & 0.38 & 0.42 & 0.45 & 0.49 & 0.44 & 0.58 & 0.45 & & & & & & \\
\hline HA 10-8 & 0.36 & 0.51 & 0.56 & 0.42 & 0.60 & 0.40 & 0.53 & 0.44 & 0.47 & 0.40 & & & & & \\
\hline FPB 21 & 0.62 & 0.58 & 0.47 & 0.55 & 0.58 & 0.65 & 0.40 & 0.53 & 0.65 & 0.44 & 0.40 & & & & \\
\hline RIL 21 & 0.42 & 0.38 & 0.35 & 0.38 & 0.36 & 0.38 & 0.40 & 0.42 & 0.38 & 0.36 & 0.40 & 0.38 & & & \\
\hline RIL 25 & 0.35 & 0.44 & 0.47 & 0.36 & 0.27 & 0.38 & 0.38 & 0.42 & 0.42 & 0.42 & 0.38 & 0.36 & 0.38 & & \\
\hline RIL 60 & 0.35 & 0.35 & 0.42 & 0.38 & 0.42 & 0.40 & 0.35 & 0.38 & 0.33 & 0.35 & 0.42 & 0.42 & 0.36 & 0.42 & \\
\hline RIL 180 & 0.31 & 0.40 & 0.58 & 0.38 & 0.51 & 0.49 & 0.45 & 0.42 & 0.36 & 0.40 & 0.42 & 0.36 & 0.31 & 0.36 & 0.56 \\
\hline
\end{tabular}


The number of alleles needed to provide same heterozygosis if all the alleles are equally frequent (Hartl and Clark, 1997) as quantified by effective number of alleles $(\mathrm{Ne})$ were more for tri-allelic SSR markers than the bi-allelic markers with an average of 2.17 alleles per marker. When allelic frequencies are similar, the estimate of effective number of alleles is close to the observed number of alleles at a locus. Therefore, large differences between observed and the effective number of alleles indicate low frequencies of a few alleles because they are present in only one or a few genotypes. For this reason, estimate of effective number of alleles could be useful in indicating rare alleles (Laurentin, 2009). In the present study, large differences between the estimates of observed and the effective number of alleles indicate relatively low frequency of a few alleles, which could be considered as rare alleles. SSR markers exhibited differential ability to discriminate 16 genotypes as indicated by the estimates of effective multiplex ratio which ranged from 1.89 to 4.73 and marker index ranged from 0.69 to 3.40 (Table 2).

\section{SSR marker-based genetic diversity}

Laurentin (2009) opined that conceptually 'gene diversity' is the most appropriate measure of genetic diversity in self-pollinated crops like dolichos bean. It has been amply demonstrated that a minimum of 50 genotypes need to be used for DNA markerbased genetic diversity assessment (Bonin, 2007). In the present study, marginal differences between standard Nei's average gene diversity estimate and unbiased gene diversity (UGD) (Table 2) suggested that 16 dolichos bean genotypes considered for the study is adequate for genetic diversity assessment. Average gene diversity as a measure of variability is more appropriate for inbreeding species such as dolichos bean and is loosely referred as average heterozygosis
(Weir, 1996). The average gene diversity was as low as 0.32 at SSR marker locus, KTD 250 and as high as 0.72 at SSR marker locus KTD 241 with an average of 0.52 among 16 genotypes. The average gene diversity in the present study is more than that reported in dolichos bean by Venkatesha et al., (2007) and (Kinmani et al., 2012), by Sarikamis et al., (2009) in common bean and by Gwag et al., (2006) in mung bean.

Shanon's diversity index, being relatively insensitive to bias caused by inability to detect heterozygous individuals (Dawson et $a l ., 1995)$ is being used to measure population diversity (Bussel, 1999). Shanon's diversity index is being largely used as a measure of diversity in plant genetic resources (Upadhayaya et al., 2007). In the present study, estimates of Shanon's diversity index complemented those of average gene diversity. These results indicate that these SSR markers are highly informative and could be used to assess genetic diversity among the genotypes.

\section{Inter-genotypic differentiation}

Most published studies do not explain the choice of coefficient of diversity in relation to the type of marker and or ploidy level and pollination control system of the crop being investigated (Kosman and Leonard, 2005). While investigating the diversity of related genotypes in predominately self-pollinated crops such as dolichos bean where only homozygous genotypes were used in the study, Simple Matching Coefficient (SMC) is the most appropriate diversity measure as it takes care of absence of the amplicons in addition to presence of the amplicons in both the compared genotypes as causes of similarity (Laurentin, 2009). Dissimilarity coefficient among 16 genotypes (Table 3) ranged from 0.65 (between the genotypes HA $10-8$ with FPB 15 and RIL 162) to 0.27 
(between FPB 8 and RIL 21). These results indicate that while HA 10-8, FPB 15 and RIL 162 share different alleles, FPB 8 and RIL 21 share similar alleles. The genotypes, HA 10-8, FPB 15 and RIL 162 could be used in crossing programme to derive genotypes with combination of desired traits. The strategy of crossing genotypes with markedly distinct DNA marker-based profile has resulted in appearance of higher proportion of $>50 \%$ of new and useful quantitative trait loci alleles in rice and tomato (Tanksley and McCouch, 1997).

\section{Acknowledgements}

Senior author gratefully acknowledges Kirkhouse Trust, UK for providing financial support in the form of fellowship for conducting thesis research for partial fulfilment for the award of $\mathrm{PhD}$ degree by University of Agricultural Sciences, Bengaluru, India.

\section{References}

Bonin, A., Ehrich, D. and Manel, S. 2007. Statistical analysis of amplified fragment length polymorphism data: A toolbox for molecular ecologists and evolutionists. Mol. Ecol. 16: 3737-3758.

Botstein, D., White, R. L., Skolick, M. and Davis, R. W. 1980. Construction of a genetic linkage map in man using restriction fragment length polymorphism. American J. Human Genet. 32: 314-331.

Bussel, J. D. 1999. The distribution of random amplified polymorphic DNA (RAPD) diversity amongst populations of Isotoma petraea (Lobeliaceae). Mol. Ecol. 8: 775789.

Dawson, I. K., Simons, A. J., Waugh, R. and Powell, W. 1995. Diversity and genetic differentiation among subpopulations of Gliricidia sepium revealed by PCR-based assays. Heredity. 74: 10-18.
Doyle, J. J. and Doyle, J. L. 1987. A rapid DNA isolation procedure for small quantities of fresh leaf tissue. Phytochem. Bull. 19: 1115.

Ebert, A. W. 2014. Potential of underutilized traditional vegetables and legume crops to contribute to food and nutritional security, income and more sustainable production systems. Sustainability. 6: 319-335.

Engle, L. M. and Altoveris, N. C. 2000. Collection, conservation and utilization of indigenous vegetables. In: Proceedings of a workshop, AVRDC, Shanhua, Taiwan, 16-18 August 1999, Asian Vegetable Research and Development Centre (AVRDC), Shanhus, Taiwan, ROC, pp.142.

Fuller, D. Q. 2003. African crops in prehistoric South Asia: A critical review. In: Neumann, K., Butler, A., Kahlheber, S., (eds.) Food, fuel, fields-progress in African archaeobotany, Heinrich-BarthInstitute, Köln, Germany. Africa Prehistorica, 15: 239-271.

Gwag. J. G., Chung, W. K., Chung, H. K., Lee, J. H., Ma, K. H., Dixit, A., Park, Y. J., Cho, E. G., Kim, T. S. and Lee, S. H. 2009. Characterization of new microsatellite markers in mungbean. Mol. Ecol. Notes. 6: 1132-1134.

Hartl, D. L. and Clark, A. G. 1997. Principles of population genetics. Sinauer, Sunderland, MA.

Kinmani, E. N., Wachira, F. N. and Kinyua, M. G. 2012. Molecular diversity of Kenyan lablab bean (Lablab purpureus L. Sweet) accessions using amplified fragment length polymorphism markers. American J. Pl. sci. 3 (3):3-32.

Kosman, E. and Leonard, K. J. 2005. Similarity coefficients for molecular markers in studies of genetic relationships between individuals for haploid, diploid, and polyploidy species. Mol. Ecol. 14(2): 415-424.

Laurentin, H. 2009. Data analysis for molecular characterization of plant genetic resources. Genet. Resour. Crop. Evol. 56: 277-292. 
Liu, K. and Muse, S. V. 2005. Power Marker: An integrated analysis environment for genetic marker analysis. Bioinformatics. 21: 2128-2129.

Magoon, M. L., Amar Singh and Mehra, K. L. 1974. Improved field bean for dry land forage. Indian Farming. 24(2): 5-7.

Pengelly, B. C. and Lisson, S. N. 2003. Strategies for using improved forages to enhance production in Bali cattle. In: Entwistle, K. and Lindsay, D.R. (eds). Strategies to improve Bali cattle in eastern Indonesia. Proceedings of a workshop 4-7 February 2002, Bali, Indonesia. ACIAR Proceedings no. 110. Australian Centre for International Agricultural Research (ACIAR), Canberra, Australia, pp.29-33.

Ramesh, S. and Byre Gowda, M. 2016. Dolichos bean genetics and breeding present status and looking ahead. In: Souvenir, National conference on sustainable and self-sufficient production of pulses through an integrated approach. UAS, Bengaluru, India, May 21-22, pp. 59-74.

Saha, M. C., Mian, M. A. R., Eujayl, I., Zwonitzer, J. C., Wang, L. J. and May, G. D. 2004. Tall fescue EST-SSR markers with transferability across several grass species. Theor. Appl. Genet. 109: 783791.

Sarikamis, G., Yasar, F., Bakir, M., Kazan, K. and Ergul, A. 2009. Genetic characterization of green bean (Phaseolus vulgaris) genotypes from eastern Turkey. Genet. Mol. Res., 8(3): 880-887.

Smartt, J. 1985. Evolution of grain legumes II. Old and new world pulses of lesser economic importance. Expt. Agric. 21: 118.

Tanksley, S. D. and McCouch, S. R. 1997. Seed banks and molecular maps: unlocking genetic potential from the wild. Science. 277: 1063-1066.

Upadhyaya, H. D., Salimath, P. M., Gowda, C. L. L. and Singh, S. 2007. New early maturing germplasm lines for utilization in chick pea improvement. Euphytica. 157: 195-208.

Venkatesha, S. C., Byregowda M., Mahadevu, P., Mohan Rao, A., Kim, D. J., Ellis, T. H. N. and Knox, M. R. 2007. Genetic diversity within Lablab purpureus and the transferability of gene-specific markers from a range of legume species. Plant Genet. Resour. Characterization and Utilization. 5:154-171.

Weir, B. S. 1996. Genetic data analysis. $2^{\text {nd }} \mathrm{ed}$. Sinauer, Sunderland, Mass.

Woodhead, M., Russell, J., Squirrell, J., Hollingsworth, P. M., Mackenzie, K., Gibby, M. et al., 2005. Comparative analysis of population genetic structure in Athyrium distentifolium (Pteridophyta) using AFLPs and SSRs from anonymous and transcribed gene regions. Mol. Ecol. 14: $1681-1695$.

Zhang, G., Xu, S., Mao, W., Gong, Y. and Hu, Q. 2013. Development of EST SSR markers to study genetic diversity in hyacinth bean (Lablab purpureus L.). Plant Omic. J. 6(4):295-301.

Zhong, S. B., Yang, B. J. and Alfenas, A. C. 2008. Development of microsatellite markers for the guava rust fungus, Puccinia psidii. Mol, Ecol, Notes. 8: 348350.

\section{How to cite this article:}

Keerthi, C.M., S. Ramesh, M. Byregowda and Vaijayanthi, P.V. 2018. Simple Sequence Repeat (SSR) Marker Assay-Based Genetic Diversity among Dolichos Bean (Lablab purpureus L. Sweet) Advanced Breeding Lines Differing for Productivity per se Traits. Int.J.Curr.Microbiol.App.Sci. 7(05): 3736-3744. doi: https://doi.org/10.20546/ijcmas.2018.705.433 